\title{
Mikotoxinok hatása az életminőségünkre
}

\author{
Kovács Melinda1,2,* \\ ${ }^{1}$ Kaposvári Egyetem Agrár- és Környezettudományi Kar, Mikotoxinok az Élelmiszerláncban Kutató- \\ csoport; ${ }^{2}$ MTA-KE-SZIE Mikotoxinok az Élelmiszerláncban Kutatócsoport, \\ 7400 Kaposvár, Guba S. u. 40.
}

\begin{abstract}
Mycotoxins affecting quality of life
Author(s): Melinda Kovács ${ }^{1,2}$

Affiliation(s): (1)Kaposvár Universty Faculty of Agricultural and Environmental Sciences, Mycotoxins in the Food Chain Research Group; (2)MTA-KE-SZIE Mycotoxins in the Food Chain Research Group,7400 Kaposvár, Guba S. street 40., Hungary

The paper is a written version of the scientific presentation given on the annual meeting of the Regional Committee of the Hungarian Academy of Sciences in Pécs (on 22 February of 2018 in Pécs). The number of people dying as a result of foodborne diseases is about 420.000. The global burden of foodborne diseases caused in 2010 was 33 million DALYs (Disability-Adjusted Life Year). Mycotoxins are secondary metabolites of fungi, found all around the world as natural contaminants, still unavoidable in the human food chain. This paper provides current data on the worldwide occurrence of mycotoxins and introduces their human health and food safety risks. It summarizes human exposure data in Europe determined by multi-biomarker analyses using human urine samples. It highlights the importance of multi-mycotoxin exposure assessments because of the complexity of mycotoxin interactions. Multi-mycotoxin contamination, the co-contamination of emerging and masked mycotoxins makes the continuous monitoring and revision of limit values necessary.
\end{abstract}

Keywords: mycotoxins, human exposure, human health effects, interactions

\section{ÖSSZEFOGLALÁS}

A közlemény az MTA Pécsi Területi Bizottsága (PAB) éves közgyűlésén (Pécs, 2018. február 22.) elhangzott tudományos előadás anyaga. Az élelmiszer eredetű megbetegedéseknek évente kb. 420000 halálos áldozata van, a megbetegedések gazdasági hatása is jelentős, kb. 33 millió egészséges életév veszteséget (Disability-Adjusted Life Year, DALYs) okoz. A mikotoxinok a penészgombák szekunder anyagcsere termékei, természetes környezetszennyező anyagok, amelyeket ma még nem lehet kiiktatni az élelmiszerláncból. A közlemény adatokat mutat be takarmányok mikotoxin szennyezettségére vonatkozón, ismerteti a mikotoxinok élelmiszerbiztonsági kockázatát. Példákat szolgáltat európai országok lakosságának mikotoxin expozíciójára, vizeletmintákban biomarkerek mérése alapján. Kiemeli a multitoxikus hatások jelentőségét, az

\footnotetext{
*CORRESPONDING AUTHOR

Kaposvári Egyetem, Agrár - és Környezettudományi Kar

$\triangle 7400$ Kaposvár, Guba S. u. 40., 疋 +36-82-505-800

E-mail: kovacs.melinda@ke.hu
} 
egyes mikotoxinok interakciójának bonyolultságát. A multitoxikus hatások, a módosított és kötött (maszkolt), valamint az ún. emerging mikotoxinok együttes szennyezése szükségessé teszi a folyamatos monitorozást és a határértékek időszaki felülvizsgálatát.

(Kulcsszavak: mikotoxin, humán expozíció, egészségügyi hatások, interakciók)

\section{BEVEZETÉS}

Az évszázad kihívása az emberek megfelelő mennyiségű és minőségű, egészséges és biztonságos élelmiszerrel való ellátása. Az élelmiszer és a táplálkozás a szervezetünk számára nélkülözhetetlen táplálóanyag forrást jelenti, de túl ezen, nagyon fontos társadalmi, családi esemény, az életminőség egyik fontos eleme, egyben hagyományok és szokások őrizője. Az élelmiszer előállítás gazdasági alappillér is. Ismert ugyanakkor, hogy a szervezetre káros anyagok több mint 70\%-a a táplálékkal illetve az ivóvízzel jut be a szervezetünkbe. Ennek megelőzését szolgálja az élelmiszerbiztonság, amelynek lényege, hogy az élelmiszer ne legyen ártalmas a fogyasztó egészségére, ha azt a szokásos módon készíti és fogyasztja el (FAO/WHO, 1969).

2010-ben jelent meg a második Eurobarometer jelentés, amely összegzi az uniós fogyasztók élelmiszerekkel összefüggő kockázatokról szóló vélekedéseit (EC, 2010). Az Európai Unió 27 tagállamának bevonásával készült a felmérés, 15 év feletti fogyasztók anyanyelvükön folytatott személyes interjúja alapján. Közel 27 ezer embert kérdeztek meg. Az élelmiszerekkel kapcsolatos tapasztalataikra vonatkozó kérdés esetében a válaszadók többsége az ételt és az étkezést az élvezettel, például a friss és ízletes élelmiszerek kiválasztásával (58\%) vagy a családi és baráti körben való étkezés örömével (54\%) hozza öszszefüggésbe. A válaszadók 37\%-át foglalkoztatja az élelmiszerbiztonság kérdése. Más kockázatokkal összehasonlítva több uniós polgár gondolja úgy, hogy a gazdasági válság (20\%) és a környezetszennyezés (18\%) nagyobb valószínűséggel gyakorol hatást az életükre, mint az élelmiszer által okozott egészségkárosodás esetleges kockázata (11\%). Az élelmiszerekkel kapcsolatos lehetséges kockázatok miatt aggódó személyeket jobban aggasztja az élelmiszerek vegyi szennyezése, mint a bakteriális szennyezés vagy az egészségügyi és táplálkozástani kérdések.

Több mint 200 élelmiszer eredetű megbetegedés ismert. A legtöbb ember élete során legalább egyszer szembekerül élelmiszerbiztonsági problémával. Minden 10. ember évente megbetegszik fertőzött vagy szennyezett élelmiszer fogyasztása miatt. Ennek évente kb. 420000 halálos áldozata van, közülük kb. 125000 gyermek. A megbetegedések gazdasági hatása is jelentős, kb. 33 millió 
egészséges életév veszteséget okoz (Disability-Adjusted Life Year, DALYs) (WHO, 2015).

\section{A MIKOTOXIN SZENNYEZETTSÉG NÉHÁNY JELLEMZŐJE}

A mikotoxinok a penészgombák másodlagos anyagcsere termékei, természetes környezetszennyező anyagok. Kialakulásuk feltétele a penészgombáknak a növényeken való elszaporodása, majd adott környezeti körülmények hatására a gomba másodlagos anyagcserére tér át és mérgező hatású vegyületeket termel. Ezek száma több ezer, de komoly állat- vagy humánegészségügyi hatása kb. 20 mikotoxinnak van. $\mathrm{Az}$ általuk elóidézett megbetegedések a mikotoxikózisok.

Az élelmiszertermelés teljes vertikumában megtalálhatóak, mennyiségüket számos biológiai, környezeti, technológiai és emberi tényező befolyásolja. A növények penészgomba fertőződése egy bonyolult gazdanövény - penészgomba interakciót eredményez. Az, hogy a penészgomba mikor és miért tér át másodlagos anyagcsere folytatásra, részleteiben még nem ismert. A védekezés, megelőzés alapja a penészgomba fertőzés megakadályozása, csökkentése.

Az ember szervezetébe a mikotoxinok bejuthatnak közvetlenül, szennyezett növényi eredetú élelmiszerek fogyasztásával, vagy állati eredetủ élelmiszerekkel, ha a takarmány a javasolt határértékeken felüli mennyiségben tartalmaz toxint és az akkumulálódik az állat fogyasztásra kerülő szerveiben, szöveteiben (pl. máj, zsír, hús), vagy kiválasztódik a tejjel vagy a tojással. Ez utóbbi, az ún. 'carry over' ritka, csak néhány mikotoxinra és néhány állati termékre jellemző (pl. az aflatoxin M1 megjelenése a tejben).

Joint Expert Committee on Food Additives (JECFA) a WHO és a FAO tudományos tanácsadó testülete, amely felméri a mikotoxinok okozta kockázatot. Ezek alapján az Egyesült Államokban a Food and Drug Administration (FDA), míg az Európai Unióban az Európai Közösség (EK) állapítja meg a szabályozott vagy ajánlati értékeket. Az EK tanácsadó testülete a European Food Safety Authority (EFSA), amely Európában a fő kockázatbecslésért felelős intézmény.

Az EU-ban mikotoxinokra vonatkozó hatályos jogszabályok, illetve ajánlások: Regulation (EC) No 1881/2006, Directive 2002/32/EC, Recommendations 2006/576/EC és 2013/165/EU. Ezek alapján szabályozás alá eső, vagy ajánlati határértékekkel rendelkező mikotoxinokról beszélünk.

Évek óta a BIOMIN kutatóközpontja végzi a legteljesebb körü monitorozást kész takarmányok és alapanyagok mikotoxinok szennyezettségre vonatkozóan (http://www.biomin.net/en/about/research/). A legújabb, 2017-ben 3/4 évet felölelő, 69 országot érintő, 13.153 mintából elvégzett 51.197 analízis 
eredményei alapján a korábbi évekhez hasonló tendencia látszik: a leggyakoribb szennyező a deoxinivalenol (DON), ezt követi a zearalenon (ZEA) és a fumonizinek (FUM). Az eltérő éghajlati viszonyok miatt jelentősek a regionális eltérések, hiszen az egyes penészgombák szaporodása és toxintermelése eltérő környezeti feltételek mellett következik be. A pozitivitás az adott analitikai módszerrel még kimutatható legkisebb mennyiséget jelent - ez a nagyon gyorsan fejlődő módszereknek és eszköz háttérnek köszönhetően egyre kisebb (1a ábra). Ennél informatívabb a megengedhető határérték feletti, kockázatot jelentő minták aránya (1b ábra).

Ezek aránya Európában láthatóan alacsony, a tendencia itt is hasonló: DON $>$ ZEA > FUM. A DON a trichotecén toxinok közül a kevésbé toxikusak közé tartozik, de immunszuppresszív hatású. A ZEA toxicitása is alacsony, de ösztrogén hatást vált ki a szervezetben. A FUM toxicitása nagyobb, és fő képviselőjük a FB1 potenciálisan rákkeltő (IARC, 1993).

Ezek a vizsgálatok felhívják a figyelmet az adott időszakban nagyobb kockázatnak kitett régiókra, valamint, az éves adatok összevetése hosszútávon a klímaváltozással kapcsolatos eltéréseket is jelezhetik. Felhívják a figyelmet továbbá arra is, hogy a mikotoxinok sosem önmagukban fordulnak elő, hanem mindig multi-toxikus hatással kell számolnunk. Egy-egy minta átlagosan 33 mikotoxint tartalmazott és a minták 97\%-ában a mikotoxinok, illetve metabolitok száma 10 és 60 között változott.

Egy hazai sertéstelepen a közvetlenül az állatok által elfogyasztott takarmány minták mikotoxin szennyezettségének felmérése azt mutatta, hogy a vizsgált minták többsége 74 mikotoxint, illetve metabolitot tartalmazott. A három leggyakoribb Fusarium toxin átlag koncentrációi 2016-ban és 2017-ben nagyon jól mutatják az időjárás hatását: 2016-ban 2017-es évhez képest melegebb és csapadékosabb nyár szignifikánsan nagyobb mennyiségeket eredményezett (2. ábra). Bár egyik minta sem mutatott egy mikotoxin esetében sem határérték feletti szennyezettséget, az eredmények felhívják a figyelmet a folyamatos monitorozás szükségességére (Szabó-Fodor és mtsai. 2018).

Élelmiszerekre vonatkozóan hasonlóan átfogó és rendszeres monitorozást nem végeznek. Az egyes élelmiszerek az alábbi mikotoxinokat tartalmazhatják a leggyakrabban: tej és tejtermékek $\left(\mathrm{AFM}_{1}\right)$, hús és hústermékek (OTA), tojás (DON, AFB $1, \mathrm{CPA})$, gabonamagvak ( $\mathrm{AFB}_{1}$, Fusarium toxinok, OTA), olajos magvak $\left(\mathrm{AFB}_{1}\right)$, bor, szőlő (OTA), sör (OTA, $\mathrm{AFB}_{1}$, Fusarium toxinok), gyümölcsök, gyümölcslevek, füszerek (OTA, citrinin, patulin, Fusarium toxinok), kávé, kakaó (OTA) (Galvano és mtsai., 2015). 


\section{1a: A pozitív minták \%-os aránya}

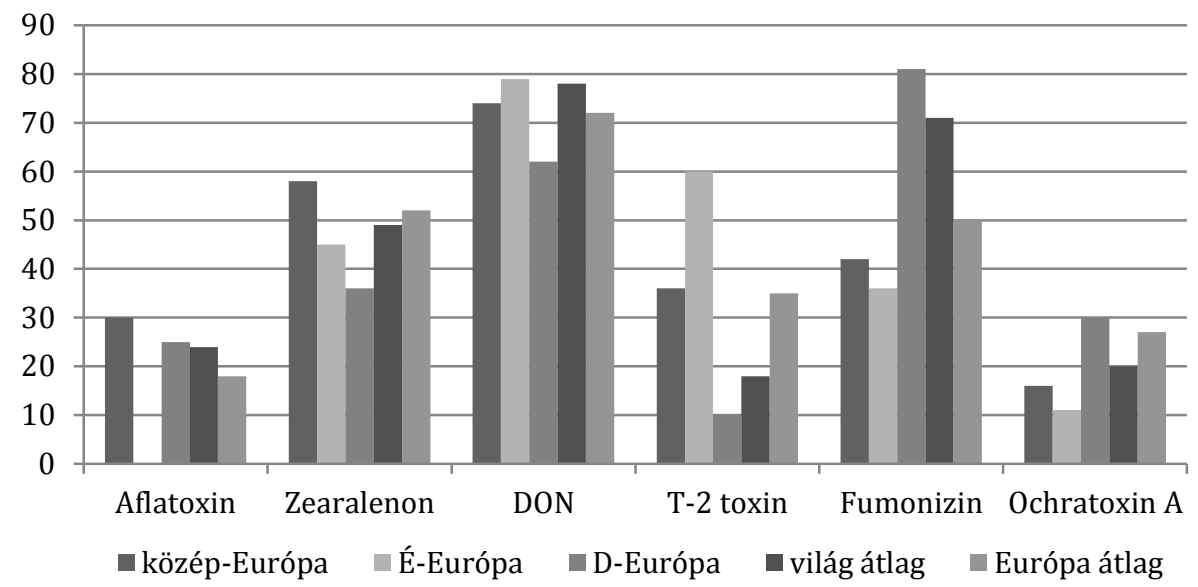

\section{1b: A kockázatot jelentő minták aránya (\%)}

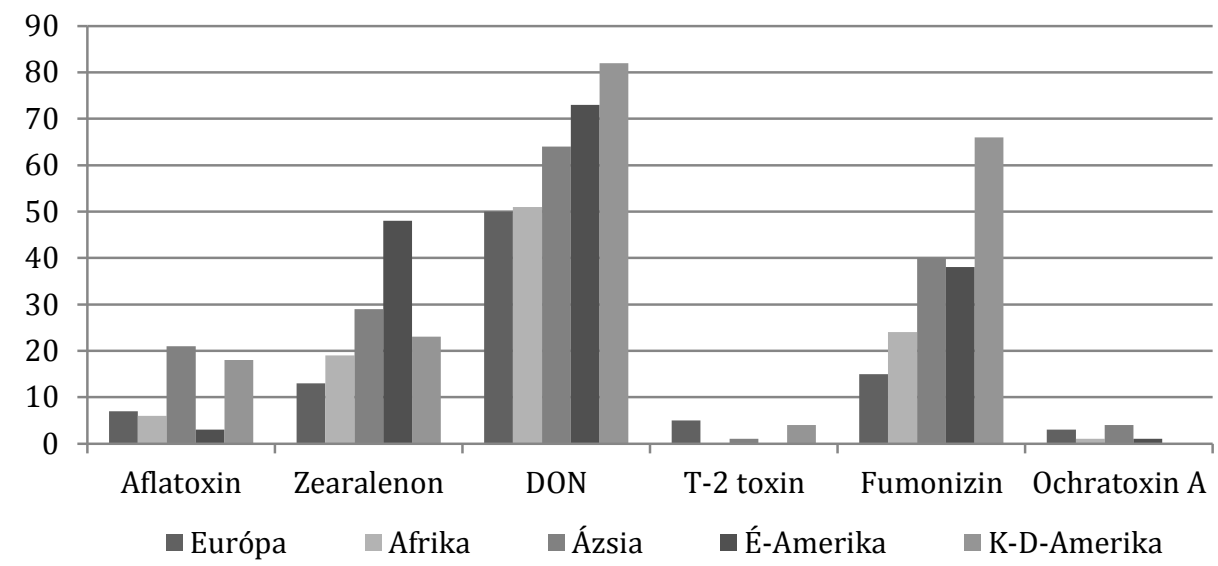

1. ábra. A BIOMIN 2017-es felmérésében a pozitív és a kockázatot jelentő takarmányminták \%-os aránya

Figure 1. Ratio (\%) of positive samples (1. a) and of those of risk (1. b) according to the mycotoxin survey of BIOMIN in 2017; Közép-Európa (Central Europe), É-Európa (Northern Europe), D-Európa (Southern Europe), világ átlag (world average), Európa átlag (European average), Európa (Europe), Afrika (Africa), Ázsia (Asia), É-Amerika (North America), K-D-Amerika (Central and South America) 

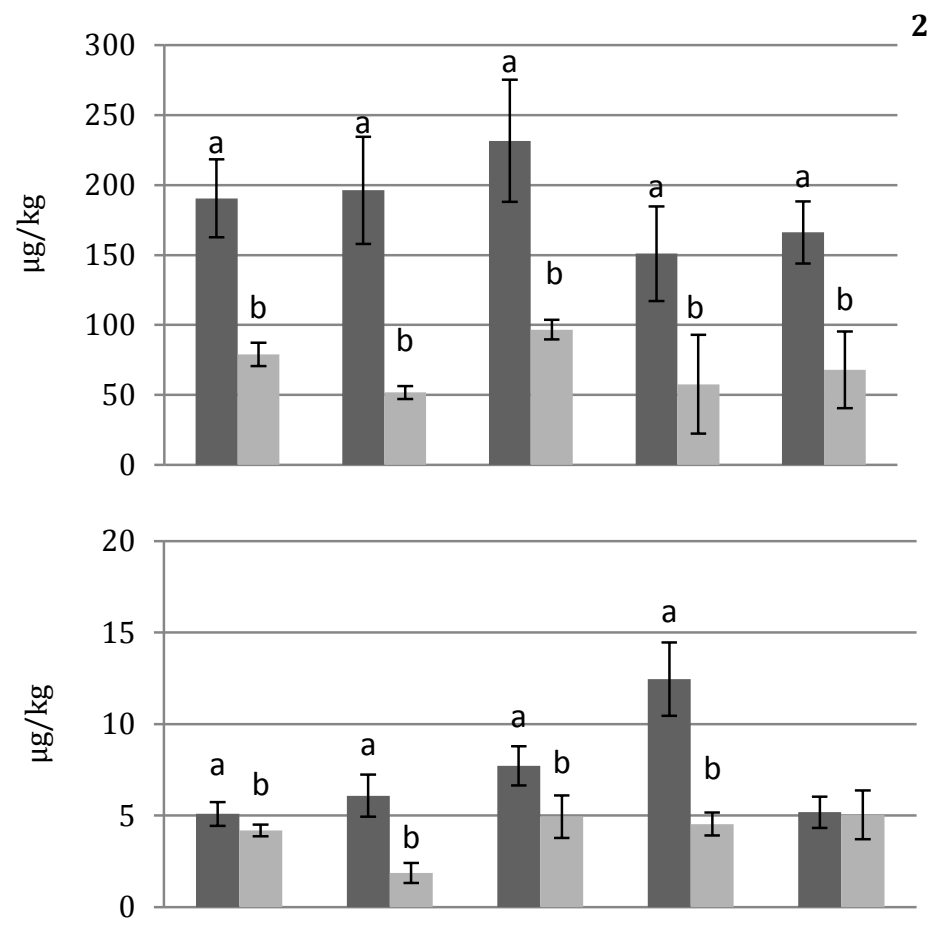

2b

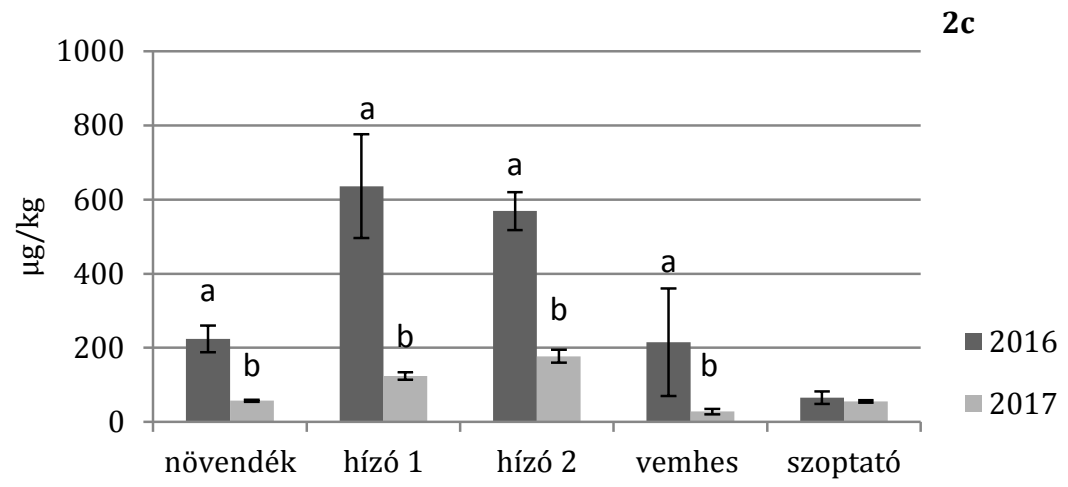

2. ábra: Hazai sertés takarmányok DON (2a), ZEA ( $2 b)$ és FB1 (2c) szennyezettsége 2016-ban és 2017-ben

Figure 2. DON, ZEN and Fumonisin B1 (2a, $2 b$ and $2 c$ respectively) contamination of complete feed for pigs in2016 and 2017; növendék (growing pigs), hízó 1, hízó 2 (fattening pigs <65 kg, 65-90 kg), vemhes (pregnant), szoptató (lactating) 
A legnagyobb kockázatot a gabonamagvak, azokon belül is a kukorica és a búza jelentik. Ezek kifejezetten érzékenyek Fusarium fajokra, amelyek már a szántóföldön fertőzik a növényt, és a betakarítás után, nem megfelelő tárolási körülmények között is képesek tovább szaporodni és toxint termelni. Valamint azért is, mert ezekből sokat fogyasztunk.

Az Európai Unió országaiban működik az ún. Gyors veszélyt-jelző rendszer (Rapid Alert System on Food and Feed, RASFF), ahová a tagállamok haladéktalanul jelentik az élelmiszerekből és takarmányokból származó, az emberi egészséget közvetve vagy közvetlenül érintő veszélyt. Az információt minden tagállam megkapja, illetve egy központi adatbázisban mindenki számára hozzáférhetőek. A mikotoxin szempontjából kockázatot jelentő élelmiszerek több mint 90\%-a aflatoxin szennyezettséget mutat, az érintett élelmiszerek többségben a harmadik országokból érkező olajos magvak, aszalt zöldségek, gyümölcsök, füszerek. A bejelentések többsége határról való visszafordításról szól.

\section{MIKOTOXINOKRA VISSZAVEZETHETŐ HUMÁN MEGBETEGEDÉSEK}

Fejlett országokban a lakosság táplálkozására nagyon változatos étrend jellemző. A szupermarketeknek, kiskereskedéseknek érdeke megfelelni a legszigorúbb minőségi és biztonsági előírásoknak. Fejlődő, vagy elmaradott országokban, illetve régiókban a lakosság táplálkozása egyoldalú, saját előállítású, vagy helyileg beszerzett alapanyagokra épül, ezek kevéssé ellenőrzöttek. Éppen ezekben az országokban hiányzik az élelmiszerbiztonsági kockázatot jelentő anyagokra (pl. mikotoxinokra) vonatkozó törvényi szabályozás, határértékek megállapítása, betartatása.

Dél-Afrikában az 1 főre jutó napi kukorica fogyasztás átlagosan 110 g. Ez esetben alacsony toxin szennyezettség esetén is meghaladhatja a napi toxinfelvétel a FAO és WHO közös szervezete a JECFA által meghatározott tolerálható határértéket, amely $2 \mu \mathrm{g} /$ testsúly kg/nap. Ugyanakkor éppen ezek azok a területek, ahol magasabb toxin szennyezettséggel kell számolni. Míg az európai országokban a lakosság a tolerálható határérték max. 10\%-át veszi fel naponta, addig az elmaradottabb régiókban a határérték többszörösét fogyasztják (840-26 400 g/testsúly kg/nap) (Marasas, 1997).

A kukorica egyoldalú fogyasztásával összefüggően kialakuló multifaktoriális betegségcsoport Afrikában az afrikai Fusarium - kukorica betegség elnevezést kapta („The African Fusarium / maize disease). A korábban ismeretlen eredetűnek tartott megbetegedések hátterében a kukorica FB1 szennyezettsége mellett egyéb tényezők is szerepelnek: a kukoricában lévő 
egyéb mikotoxinok (főként zearalenon, trichotecének és aflatoxin), a kukorica alacsony fehérje és vitamintartalma, valamint egyéb hajlamosító hatások. A betegek véréből ki lehetett mutatni a FB1-et. Ismerve azt, hogy a FB1 kis mértékben szívódik fel és viszonylag gyorsan kiürül, ez azt jelzi, hogy ezek az emberek folyamatosan, viszonylag nagy expozíciónak vannak kitéve (Dutton, 2009).

Fejlődő országok elmaradottabb régióiban még ma is előfordulhatnak akut megbetegedések. A legutóbbi súlyos eset Kenyában történt, 2004-ben, akut aflatoxin mérgezés, helyileg termesztett és nem megfelelően tárolt kukorica fogyasztását követően. 317 beteget regisztráltak akut hepatitis-sel, közülük 125-en meghaltak. A megvizsgált minták több mint 50\%-ában az AFB1 tartalom meghaladta a megengedett határértéket (20 $\mu \mathrm{g} / \mathrm{kg})$, számos esetben 50 400 szoros mennyiséget mértek (Azziz-Baumgartner és mtsai. 2005).

\section{KOCKÁZATBECSLÉS}

A kockázatbecslés a korszerű élelmiszerbiztonsági rendszer alapját képezi. Célja, tudományos ismeretekre alapozva meghatározni azt, hogy az élelmiszerben a vizsgált egészségkárosító anyag (pl. mikotoxin) milyen mértékben van jelen, és ez az elfogyasztott mennyiség, valamint az illető anyag toxicitása függvényében milyen mértékű és milyen jellegű egészségkockázatot jelent (3. ábra).

\section{Kockázatbecslés}

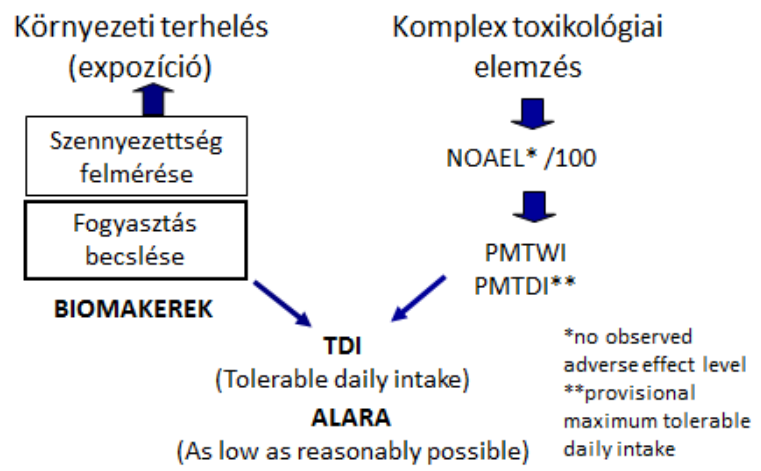

3. ábra. A kockázatbecslés főbb elemei

Figure 3. Main components of risk assessment; Környezeti terhelés (environmental exposure), szennyezettség felmérése (assessment of contamination), fogyasztás becslés (assessment of consumption), komplex toxikológiai elemzés (complex toxicological characterisation), biomarkerek (biomarkers) 
A Kaposvári Egyetemen kutatásaink fő iránya több mint 20 éve a kockázatbecsléshez adatokat szolgáltatni.

A környezeti terhelés meghatározásához takarmányok és élelmiszerek mikotoxin tartalmának monitorozását végezzük, a toxikológiai vizsgálatokkal pedig a tolerálható határértékek meghatározáshoz szolgáltatunk alapadatokat. A kockázatbecslés legtöbb bizonytalansággal terhelt tényezője a fogyasztás becslése, azaz, hogy adott élelmiszerféleségből mennyit fogyasztunk. Az expozícióbecslés pontosabb és nagyon fontos lehetősége a biomarkerek alapján történő felmérés.

Az élelmiszerminták mikotoxin tartalmának monitorozása nagyon hasznos a kockázatos földrajzi területek meghatározásában, de fogyasztási adatok nehéz becslése miatt nem ad pontos tájékoztatást a tényleges mikotoxin felvételre. A human expozícióbecslés sokkal pontosabb a vizeletminták mikotoxin tartamának meghatározása alapján, amely ma az egyetlen validált, elfogadott módszer az expozíció becslésben.

Számos felmérés igazolta azt, hogy az emberek is folyamatosan ki vannak téve mikotoxinok hatásának. A mai modern analitikai módszerek elterjedésének köszönhetően nő azoknak a felméréseknek a száma, amelyek azt igazolják, hogy a szervezet multi-toxikus hatásoknak van kitéve. Ennek oka: adott környezeti feltételek több penészgomba elszaporodásának kedveznek. Egy-egy penészgomba egyszerre több mikotoxint is termel. Az állatok takarmánya többféle alapanyagból kerül összeállításra, amelyek különböző toxinokat tartalmazhatnak. Ezek földrajzi eredete is eltérő lehet. Még bonyolultabb a helyzet az ember esetében, hiszen a táplálékok köre sokkal tágabb, pl. az élvezeti termékek vagy füszerek is számos mikotoxinnal lehetnek szennyezettek (kávé, paprika, sör, üdítő italok).

Egy németországi tanulmányban egészséges emberek vizeletmintájából végeztek multitoxin analízist (23 mikotoxinra ill. metabolitra). A minták 87\%a pozitív volt, és ezen belül a minták több mint fele egynél több toxint tartalmazott. A leggyakoribb mikotoxinok a DON és annak metabolitjai voltak. Az átlagos expozíció alacsony volt (0,52 $\mu \mathrm{g} / \mathrm{kg}$ testsúly/nap), de a számítások szerint a vizsgált egyedek 12\%-a esetében a DON terhelés meghaladta a megállapított tolerálható határértéket (1 $\mu \mathrm{g} / \mathrm{kg}$ testsúly/nap, SCF, 2002) (Gerding és mtsai. 2014). Hasonló felméréseket több európai országból is publikáltak. Az 1. táblázatban hivatkozott szakirodalmak európai országokban végzett felmérések eredményeit tartalmazzák, kiemelve azt, hogy a vizsgálat egyedek hány \%-a esetében haladta meg a bevitel a tolerálható határértékeket. Az egyes ta- 
nulmányok eredményei nehezen összehasonlíthatóak, hiszen az egyes országokban eltérő módszertannal dolgoztak, pl. a vizsgálatba vont egészséges emberek kiválasztásának kritériumai, egyedszám, a vizelet mintavételezésének módja, mikotoxin analitika, stb.. Ezek a módszertani eltérések szignifikánsan befolyásolják a kapott eredményeket. Ez felhívja a figyelmet arra is, hogy nagy szükség lenne egységes módszertan kidolgozására és annak alkalmazására rendszeres monitorozás keretében.

\section{1. táblázat}

Vizeletminták DON tartalma alapján számított DON expozíció néhány európai országban

\begin{tabular}{|c|c|c|c|}
\hline Ország & $\mathbf{P D I}^{1}$ & $\begin{array}{c}\text { TDI }^{2} \text { felett } \\
(\%)\end{array}$ & Hivatkozás \\
\hline Ausztria $^{3}$ & $0,38-2,2$ & 33 & Warth et al. (2012) \\
\hline Belgium $^{4}$ & $0,03-10,08$ & $16-39$ & Heyndrickx et al. (2015) \\
\hline Egyesült Királyság5 & $0,008-1,244$ & 17 & Turner et al. (2010) \\
\hline Horvátország6 & $0,1-33,1$ & 48 & Sarkanj et al. (2012) \\
\hline Olaszország7 & 5,9 & 6 & Solfrizzo et al. (2014) \\
\hline Spanyolország8 & 0,06-1,07 & 8 & Rodriguez-Carraso et al. (2014) \\
\hline Svédország9 & $0,002-5,448$ & 1 & Wallin et al. (2013) \\
\hline
\end{tabular}

Table 1. Human DON exposure in some European countries calculated by the DON content of urine samples; (3) Austria, (4) Belgium, (5) United Kingdom, (6) Croatia, (7) Italy, (8) Spain, (9) Sweden

\section{MIKOTOXINOK LEHETSÉGES KÖLCSÖNHATÁSAI}

A multi-mikotoxin szennyezettség felveti a toxinok interakciójának kérdését. Több toxin együttes hatása nem becsülhető előre az egyes toxinok önálló hatása alapján, hiszen azok egymás hatását felerősíthetik, vagy antagonista módon is hathatnak. Az interakció jellegét számos tényező befolyásolja: állatfaj, életkor, toxinkoncentráció, hatás időtartama, az érintett/vizsgált szerv, vizsgálta paraméter, stb. (Grenier és Oswald, 2011). Az irodalmi adatok alapján az együttes hatás az esetek többségében jelentősebb, mint azt a két toxin különkülön kifejtett hatása alapján becsüljük („Az egész több, mint a részek összessége”, Arisztotelész, 384-322 BC). A problémakör felveti a tolerálható határértékek és a szabályozás megfelelő voltának kérdését, tekintettel arra, hogy ezek a mikotoxinok önálló toxicitása alapján kerültek meghatározásra. Hogyan befolyásolhatják egyes toxin kölcsönhatások a mikotoxinokra meghatározott tolerálható értékeket?

A multitoxikus hatásokat vizsgáló kísérleteket összevetve azt tapasztaltuk, hogy kevés az alacsony dózisú mikotoxin kölcsönhatás vizsgálat. A legtöbb 
adat aflatoxinra vonatkozik, kevesen vizsgálták Fusarium toxinok együttes hatását.

Ezért vizsgálat sorozatot indítottunk el a leggyakoribb Fusarium toxinok együttes hatásának megismerésére. A vizsgálatok egy részében in vitro cito- és genotoxicitási tesztben vizsgáljuk a mikotoxinok önálló, kettős és hármas kombinációiban a koncentráció és az expozíciós idő függvényében kifejtett hatást. A vizsgálatok másik részében bizonyos toxin kombinációkat állatkísérletekben tesztelünk. Ezek eredményeit részletesen publikációink mutatják be (Hafner és mtsai. 2016; Kachlek és mtsai. 2017; Szabó és mtsai. 2018; Szabó-Fodor és mtsai. 2015). Eredményeink igazolják a multitoxikus hatások bonyolultságát. Egy toxikus molekula több mechanizmust is érint a sejt vagy a szervezet szintjén, ugyanakkor egy adott sejtválaszra más toxikus vegyületek is hatnak. Minden egyes toxin molekula esetében meg kell vizsgálni a toxin és a cél sejt molekuláris interakcióját. Ezek együttes hatását rendszerbiológiai szemlélettel, a rendszerbiológia módszereivel (genomika, transzkriptomika, proteomika, metabolomika $=$ „omikák”) lehet megközelíteni.

\section{AKTUÁLIS KIHÍVÁSOK A MIKOTOXIN KUTATÁSOKBAN}

A kutatások egyik kiemelt kérdésköre továbbra is a fentiekben vázolt interakciók problémaköre. A mikotoxinokra vonatkozó kockázatbecslést ugyanis megnehezíti a mikotoxinok együttes előfordulása, a köztük kialakuló interakciók bonyolult, előre nehezen meghatározható volta.

A helyzetet tovább bonyolítja az, hogy számos olyan metabolitot találtak takarmány és élelmiszer alapanyagokban, amelyek rutin analitikai módszerekkel nem mutathatóak ki, mert különböző módon kötött, vagy módosult formában vannak jelen, viszont a gyomor - béltraktusban emésztőenzimek hatására felszabadulnak és felszívódnak. Ez azt eredményezi, hogy az expozíció magasabb (akár 30-40\%-al), mint azt a mikotoxin analitikai eredmények alapján becsüljük. Ez magyarázatot adhat arra, hogy miért okoznak egyes mikotoxinok alacsony koncentrációban is súlyos tüneteket.

A helyzetet tovább bonyolítja az ún. „emerging” mikotoxinok jelenléte. A leggyakrabban fertőző Fusarium penészgombák ugyanis a „klasszikus” toxinok mellett (trichotecének, zearalenon, fumonizinek) társ-szennyezőként más, kevéssé ismert toxikus másodlagos anyagcseretermékeket is termelnek, ezeket a szakirodalom „emerging” mikotoxinokként említi. Mivel akut toxikózist általában nem okoznak, a rutin mikotoxin analitikai vizsgálatok során általában nem vizsgálják. Gyakori előfordulásuk mg/kg mennyiségben ugyanakkor kockázatuk felmérését teszi indokolttá. 
Kihívást jelent a klímaváltozás is. Mivel a penészgombák szaporodása és toxintermelése döntően a környezeti hőmérséklettől és a csapadék mennyiségétől függ, nagyon valószínűsíthető a mikotoxin profil megváltozása.

A mikotoxin kérdés globális összefogást igényel, nemcsak az egyes tudományterületek (mikológia, biokémia, növény kórtan, analitikai kémia, molekuláris biológia, toxikológia, élelmiszertudomány, orvostudomány, klímakutatás, ökológia, stb.) között, hanem a kutatásban dolgozók és a gyakorlati szakemberek, a jogalkotásban, szabályozásban, finanszírozásban stb. illetékes emberek és szervezetek között is.

\section{KÖSZÖNETNYILVÁNÍTÁS}

A témához kapcsolódó kutatásokat, valamint a publikációk megjelenését a következő projektek támogatták: TÁMOP-4.2.2.A-11/1/KONV-2012-0039, GINOP-2.2.1-15-2016-00021， GINOP 2.3.2-15-2016-00046, EFOP-3.6.3VEKOP-16-2017-00005.

\section{IRODALOM}

Azziz-Baumgartner, E., Lindblade, K., Gieseker, K, Rogers, H.S., Kieszak, S., Njapau, H., Schleicher, R., McCoy, L.F., Misore, A., DeCock, K., Rubin, C., Slutsker, L. (2005) Case-control study of an acute aflatoxicosis outbreak, Kenya, 2004. Environ. Health Persp., 113(12): 1779-1783. DOI: 10.1289/ehp.8384

BIOMIN, World Mycotoxin Survey, The Global Threat, January to September 2017 http://www.biomin.net/en/articles/biomin-world-mycotoxin-survey-q3-2017/

Dutton, M.F. (2009) The African Fusarium/maize disease. Mycotoxin Res., 25: 29-39. DOI: 10.1007/s12550-008-0005-8

European Commission (2010) Special Eurobarometer. Food-related risks. Report. pp. 78.

FAO/WHO (1969) General principles of food hygiene CAC/RCP 1-1969, rev-4 in 2003

Galvano, F., Ritieni, A., Piva, G., Pietri, A. (2005) Mycotoxins in the human food chain. In: The mycotoxin blue book (ed.: Diaz, D.), Nottingham University Press, Nottingham, England, 187-224.

Gerding, J., Cramer, B., Humpf, H. U. (2014) Determination of mycotoxin exposure in Germany using an LC-MS/MS multibiomarker approach. Mol. Nutr. Food Res., 58. 2358-2368. DOI: $10.1002 / m n f r .201400406$

Grenier, B., Oswald, I.P. (2011) Mycotoxin co-contamination of food and feed: meta-analysis of publications describing interactions. World Mycotoxin J., 4. 285-313. DOI: 10.3920/wmj2011.1281

Hafner, D., Szabó, A., D’Costa, L., Szabó-Fodor, J., Tornyos, G., Blochné Bodnár, Zs., Ölbeiné Horvatovich, K., Baloghné Zándoki, E., Bóta, B., Kovács, M. (2016)_Individual and combined effects of feed artificially contaminated with with fumonisin B 1 and T-2 toxin in weaned rabbits. World Mycotoxin J., 9. 613-622. DOI: 10.3920/wmj2016.2067

Heyndrickx, E., Sioen, I., Huybrechts, B., Callebaut, A., De Henauw, S., De Saeger, S. (2015) Human biomonitoring of multiple mycotoxins in the Belgian population: Results of the BIOMYCO study. Environ. Int., 84. 82-89. DOI: 10.1016/j.envint.2015.06.011

IARC (1993) Toxins derived from Fusarium moniliforme: fumonisins B1 and B2 and fusarin C. IARC Monogr. Eval. Carcinog. Risk Hum., 56. 445-466. 
Kachlek, M., Szabó-Fodor, J., Blochné Bodnár, Zs., Horvatovich, K., Kovács, M. (2017) Preliminary results on the interactive effects of deoxynivalenol, zearalenone and fumonisin B1 on porcine lymphocytes. Acta Vet. Hung., 65. 340-353. DOI: 10.1556/004.2017.033

Marasas, W. F. O. (1997) Risk assessment of fumonisins produced by Fusarium moniliforme in corn. Cereal Res. Comm., 25. 399-406.

Rodriguez-Carrasco, Y., Molto, J. C., Manes, J., Berrada, H. (2014) Exposure assessment approach through mycotoxin/creatinine ratio evaluation in urine by GC-MS/MS. Food Chem. Toxicol., 72.6975. DOI: $10.1016 /$ i.fct.2014.07.014

Sarkanj, B., Warth, B., Uhlig, S., Abia, W.A., Sulyok, M., Klapec, T., Krska, R., Banjari, I. (2013) Urinary analysis reveals high deoxynivalenol exposure in pregnant women from Croatia. Food Chem. Toxicol., 62. 231-237. DOI: 10.1016/j.fct.2013.08.043

Scientific Committee on Food (SCF): Opinion of the Scientific Committee on Food on Fusarium toxins. Part 6: Group evaluation of T-2 toxin, HT-2 toxin, nivalenol and deoxynivalenol. SCF/CS/CNTM/MYC/27 Final 27 February 2002, Brussel, Belgium

Solfrizzo, M., Gambacorta, L., Visconti, A. (2014) Assessment of multi-mycotoxin exposure in Southern Italy by urinary multi-biomarker determination. Toxins, 6. 523-538. DOI: $10.3390 /$ toxins6020523

Szabó, A., Szabó-Fodor, J., Fébel, H., Mézes, M., Balogh, K., Bázár, Gy., Kocsó, D., Omeralfaroug Ali, Kovács, M. (2018)_Individual and combined effects of fumonisin B1, deoxynivalenol and zearalenone on the hepatic and renal membrane lipid integrity of rats. Toxins, 10(1): 4. DOI: 10.3390/toxins10010004

Szabó-Fodor, J., Kachlek, M., Cseh, S., Somoskői, B., Szabó, A., Blochné Bodnár, Zs., Tornyos, G., Mézes, M., Balogh, K., Glávits, R., Hafner, D., Kovács, M. (2015)_Individual and combined effects of subchronic exposure of three Fusarium toxins (fumonisin $B$, deoxynivalenol and zearalenone) in rabbit bucks. J. Clin. Toxicol., 5: 264. DOI: 10.4172/2161-0495.1000264

Szabó-Fodor J., Bóta B., Mihucz G., Sulyok, M., Tenke J., Kovács M. (in press) Hazai sertés takarmányok multi-mikotoxin szennyezettségének felmérése. Magyar Állatorvosok Lapja

Turner, P. C., Hopton, R. P., Lecluse, Y., White, K. L. M., Fisher, J., Lebailly, P. (2010) Determinants of urinary deoxynivalenol and de-epoxy deoxynivalenol in male farmers from Normandy, France. J. Agric. Food. Chem., 58. 5206-5212. DOI: 10.1021/if100892v

Wallin, S., Hardie, L. J., Kotova, N., Lemming, E. W., Nalsen, C., Ridefelt, P., Turner, P. C., White, K. L. M., Olsen, M. (2013) Biomonitoring study of deoxynivalenol exposure and association with typical cereal consumption in Swedish adults. World Mycotoxin J., 6. 439-448. DOI: $\underline{10.3920 / w m j 2013.1581}$

Warth, B., Sulyok, M., Fruhmann, P., Berthiller, F., Schuhmacher, R., Hametner, C., Adam, G., Frohlich, J., Krska, R. (2012) Assessment of human deoxynivalenol exposure using an LC-MS/MS based biomarker method. Toxicol. Lett., 211. 85-90. DOI: 10.1016/j.toxlet.2012.02.023

World Health Organization (2016) 10 facts on food safety. http://www.who.int/features/factfiles/food safety/en/ 